\title{
Reactions of 3,3'-Linked Bispyrroles with Carbon Electrophiles
}

\author{
Alexander Lücht, ${ }^{[a]}$ Peter G. Jones, ${ }^{[b]}$ and Daniel B. Werz ${ }^{*[a]}$
}

\begin{abstract}
The reactivity of $3,3^{\prime}$-linked bispyrroles, easily accessible by ring-enlargement reactions of donor-acceptor cyclopropanes, towards various carbon electrophiles was investigated. A biscyclopropanated furan, equipped with imines as acceptor units, was converted by rearrangement and subsequent elimination of water to 3,3'-linked bispyrroles. Thereby the nucleophilic 2-position of the pyrroles stayed unsubstituted, thus permitting a further reaction with electrophiles. The heterocycles were reacted with oxalyl chloride to form a new six-membered ring between the pyrrolic subunits. The 1,2diketone moiety in these species was used as a starting point to extend the $\pi$-system via a condensation reaction with aromatic 1,2diamines. The reaction of 3,3'-linked bispyrroles with the phosgene surrogate triphosgene led to a seven-membered anhydride. The use of the Vilsmeier reagent led to a formylation of the bispyrroles. Furthermore, a direct oxidative coupling between two bispyrroles resulted in a previously unknown linkage $\left(3,3^{\prime}: 2^{\prime}, 2^{\prime \prime}: 3^{\prime \prime}, 3^{\prime \prime \prime}\right)$ between four pyrrole subunits.
\end{abstract}

\section{Introduction}

One of the most important heterocyclic motifs found in nature is pyrrole. Although the unsubstituted compound itself $\left(\mathrm{C}_{4} \mathrm{H}_{5} \mathrm{~N}\right)$ does not occur naturally, a considerable variety of pyrrole and oligopyrrole derivatives have found widespread use in living systems. The most abundant pyrrole derivatives are the porphyrins, in which four pyrrole subunits are tethered in their 2positions by one carbon atom in a cyclic fashion. Nature uses this and related cores to coordinate metal ions, e.g. iron in heme, ${ }^{[1]}$ magnesium in chlorophyll|[2] and cobalt in vitamin $\mathrm{B}_{12} \cdot{ }^{[3]}$ The direct C-C-linkage of pyrrole moieties to 2,2'-linked bispyrroles and oligopyrroles is also well known. Numerous methods for the synthesis of 2,2'-linked oligopyrroles have been developed, including Vilsmeier condensations, ${ }^{[4]}$ Paal-Knorr cyclizations, ${ }^{[5]}$ dipolar cycloadditions, ${ }^{[6]}$ Ullmann couplings ${ }^{[7]}$ and other metalmediated transformations. ${ }^{[8]}$ Such compounds have found wide applications, e.g. in material science ${ }^{[9]}$ since a high electron mobility within the $\pi$-system is guaranteed. In the widest sense the structures can be regarded as heteroatom-linked analogs of a fully conjugated carbon chain (Figure 1).

[a] M. Sc. Alexander Lücht, Prof. Dr. Daniel B. Werz

Technische Universität Braunschweig

Institut für Organische Chemie

Hagenring 30, 38106 Braunschweig, Germany

E-mail: d.werz@tu-braunschweig.de

Homepage: www.werzlab.de

[b] Prof. Dr. Peter G. Jones

Technische Universität Braunschweig

Institut für Anorganische und Analytische Chemie

Technische Universität Braunschweig

Hagenring 30, 38106 Braunschweig, Germany

Supporting information for this article is given via a link at the end of the document.

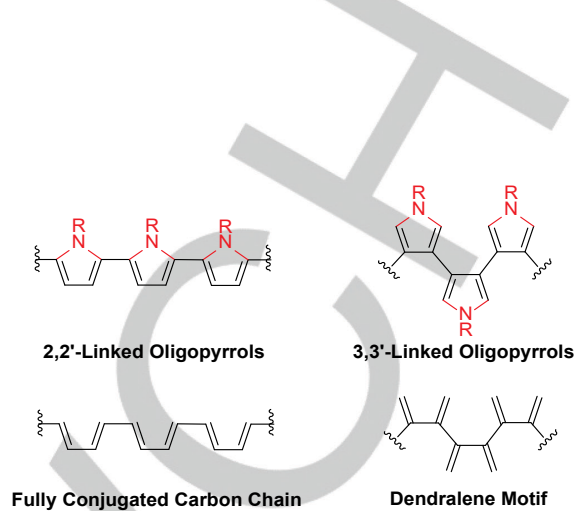

Figure 1. 2,2'-Linked and 3,3'-linked oligopyrroles and its relation to fully conjugated carbon chains and dendralene motifs.

In contrast, the direct linkage of pyrrole units at position 3 would lead to a heteroatom-linked dendralene-like structure (Figure 1). ${ }^{[10]}$ Even these simple considerations suggest that the stability of 3,3'-linked derivatives is less than that of the corresponding $2,2^{\prime}$-linked counterparts; this is consistent with the fact that few methods for their preparation have been developed. 3,3'-Linked bispyrroles have been generated by Gleiter via Pd-catalyzed rearrangements of bisazacyclodiynes, ${ }^{[11]}$ Barton-Zard syntheses of pyrrole derivatives, ${ }^{[12]}$ the transformation of 1,4-diketone dioximes with acetylene, ${ }^{[13]}$ oxidative couplings ${ }^{[14]}$ and by Michael addition reactions involving diaryl acetylene, 1,3-dicarbonyls with ammonium acetate ${ }^{[15]}$ and copper-catalyzed starting from homopropargylic amines. ${ }^{[16]}$ Magnus and co-workers were able to prepare $\mathrm{N}$-tosyl-substituted oligopyrroles such as $\mathbf{3}$ via a repetitive sequence using cyanosubstituted alkenes (e.g. 1) and, as electrophilic reagent, ( $p$-toluenesufonyl)methyl isocyanide (Scheme 1a). ${ }^{[17]}$ In their synthesis the high reactivity of these motifs was moderated by the strongly electron-withdrawing tosyl group attached to the nitrogen, thus decreasing the nucleophilicity of the ri-system.

In 2012 we reported a strategy for the preparation of 3,3'-linked bis- and oligopyrroles by use of donor-acceptor (D-A) cyclopropanes (Scheme 1b). ${ }^{[18]}$ These spring-loaded entities ${ }^{[19]}$ have enjoyed a renaissance in recent years, and numerous reports leading to a large variety of carbo- and heterocycles either by rearrangement ${ }^{[20]}$ or cycloaddition reactions ${ }^{[21]}{ }^{[22]}$ have been published. Because our protocol has the advantage of introducing the nitrogen atoms in the final step of the synthetic route, even highly electron-rich congeners are available. The key to accessing the pyrrole subunit is a cascade of imine formation (to afford 5), rearrangement of the emerging D-A cyclopropane with an oxygen donor and an imine acceptor (to generate 6) terminated by the elimination of water. As final product electronrich 3,3'-linked bispyrrole 7 is obtained. 


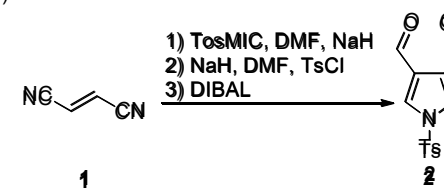

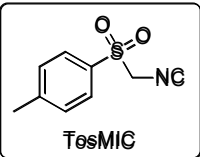

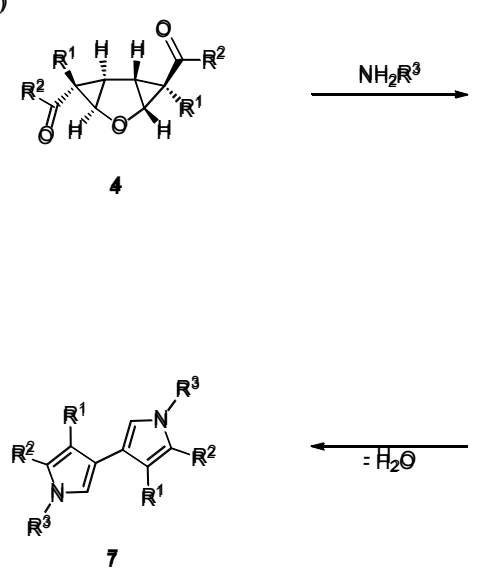
2) TosMIC, DMF, $\mathrm{NaH}$ 3) $\mathrm{NaH}, \mathrm{DMF}, \mathrm{TsCl}$

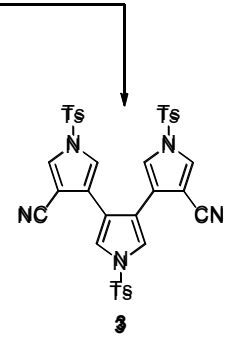

1) $(\mathrm{EtO})_{2} \mathrm{P}(\mathrm{O}) \mathrm{CH}_{2} \mathrm{CN}, \mathrm{NaH}$

\section{Results and Discussion}

To begin probing the nucleophilicity of the 3,3'-linked bispyrroles towards carbon electrophiles, substrate 7 was examined in the reaction with oxalyl chloride (Scheme 3 ). Our intention was to install a further tether, consisting of two adjacent carbonyl moieties, between the 2-positions of each pyrrole subunit. We expected that such a strong electron-withdrawing group would stabilize the bispyrrole scaffold and might serve as an excellent handle for follow-up chemistry, in order to extend the $\pi$-system by a simple condensation reaction. The dione-bridged bispyrroles were obtained in yields up to $83 \%(\mathbf{1 0 b})$. A substituent at the 4-position of each heterocycle decreased the product formation, probably because of steric repulsion between the two additional methyl groups (10c, 68\%). The reaction was not possible with electron-withdrawing substituents at the nitrogen (e.g. tosyl groups), which markedly decrease the nucleophilicity at the 2-position of the pyrroles.

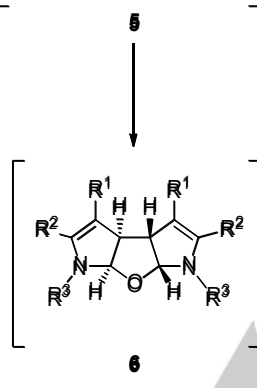

Scheme 1. (a) Synthesis of Magnus leading to oligopyrroles and (b) our approach via a cascade reaction starting from donor-acceptor cyclopropanes.

These bispyrroles were shown to act as excellent nucleophiles, comparable with enamines and ketene acetals. Initial studies at that time demonstrated that they are able to react with p-benzoquinone, maleic anhydride or maleic imide to form pyrroloindoles 8 and 9 (Scheme 2). The yields in these transformations correlated well with the electron-releasing ability of the substituent at the nitrogen; the more electron-withdrawing the substituent, the lower the yield. These investigations prompted us to study the reactivity of 3,3'-linked bispyrroles towards several other carbon electrophiles. Some of these results are reported in this paper.

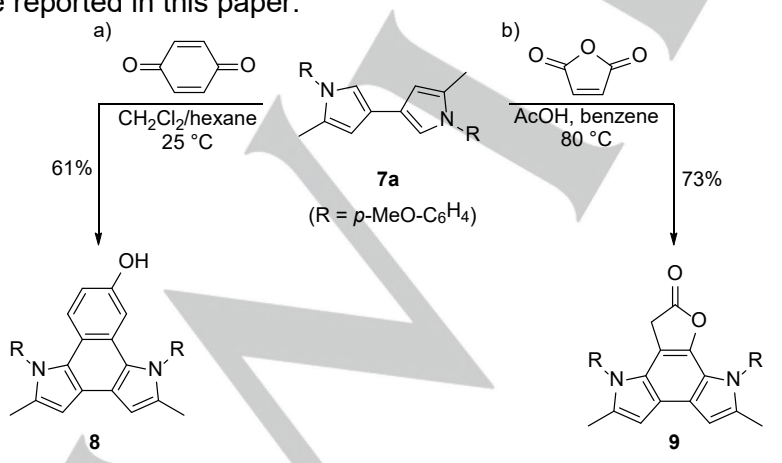

Scheme 2. Reaction of 3,3-linked bispyrrole with (a) p-benzoquinone and (b) maleic anhydride.

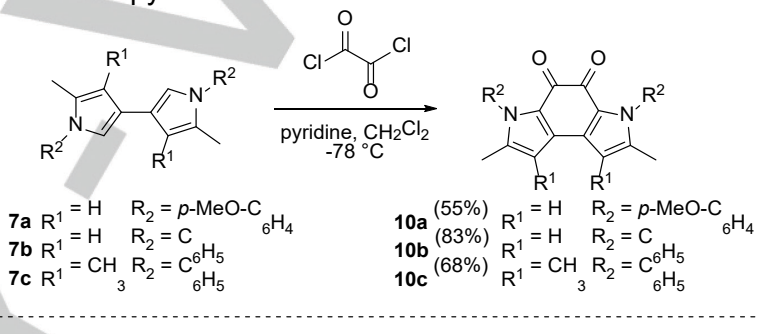

Scheme 3. Reaction of 3,3'-linked bispyrroles with oxalyl chloride (top) and further enlargement of the $\pi$-system by imine formation with 1,2-diaminobenzene derivatives (bottom).

A condensation reaction between the two newly formed carbonyl moieties and 1,2-diaminobenzene derivatives to extend the $\pi$-system proved to be quite challenging. The high electron density of the annulated pyrroles makes these carbonyls much less electrophilic than originally expected. Therefore, typical reaction conditions for a condensation reaction under Brønsted acid catalysis were not successful. Only a change to the Lewis acid $\mathrm{BF}_{3} \cdot \mathrm{OEt}_{2}$, together with the use of hexafluoroisopropanol as solvent at $150{ }^{\circ} \mathrm{C}$ in a microwave oven, promoted the desired imine synthesis. The product formation depended on the nucleophilicity of the diamine. An electron-rich and thus more nucleophilic diamine such as 4,5-dimethylbenzene-1,2-diamine led to a higher yield of $77 \%(\mathbf{1 2 b})$ whereas the product formation with the unsubstituted diamine dropped to a moderate yield of $43 \%$ (12a). The introduction of a further methyl substituent at the 4-position at each pyrrole unit increases the electron density at 
the carbonyl carbons and lowers the imine formation (12c, 43\%) compared to compound $\mathbf{1 2 b}$.

After having established a method for the synthesis of a diketone tether between the bispyrrole units, we tried to shorten the linkage to one carbonyl leading to a five-membered ring. Because of the high toxicity of phosgene we used triphosgene as surrogate (Scheme 4). Surprisingly, the seven-membered anhydride 13 was formed rather than the desired carbonyl-bridged five-membered ring. Although we have a strong evidence for the formation of this highly unstable product by LC/MS and ${ }^{1} \mathrm{H}$ NMR, its complete characterization was not possible in our hands. Therefore, we subjected the crude product directly to a reduction with sodium borohydride in methanol and obtained the dimethylester 14 in a moderate yield of $53 \%$. Mechanistically, we propose for the anhydride formation in the first step the electrophilic substitution with two activated carbonyl moieties $\left(\mathrm{COCl}\right.$ and/or $\left.\mathrm{COOCCl}_{3}\right)$.

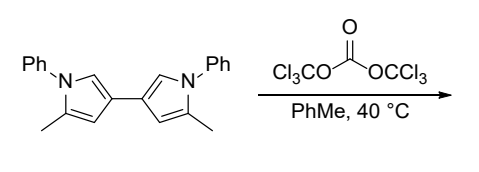

$7 b$
13
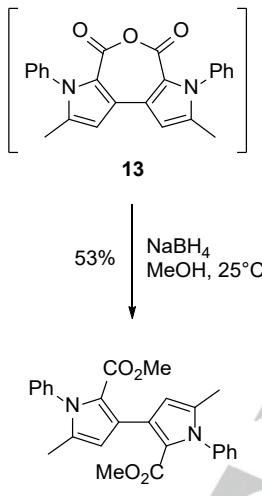

14

Scheme 4. Reaction of 3,3'-linked bispyrrole with triphosgene.

We expected that 3,3'-linked bispyrroles could also be reacted with iminium ions because their reactivity is comparable to that of carbonyls (Scheme 5). The expected nucleophilic attack of the 2position of the pyrrole on the well-known Vilsmeier reagent indeed took place, and after aqueous work-up the desired aldehyde was formed in $58-77 \%$ yields (15a-15b). The monoformylated product was also achieved in $41 \%$ yield, but the reaction was not selective The introduced aldehydes might be interesting starting points for further functionalizations of the 3,3'-linked bispyrrole system.

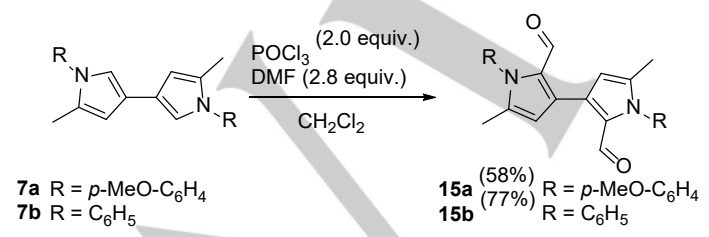

Scheme 5. Reaction of 3,3'-linked bispyrroles under Vilsmeier-Haack conditions.

To the best of our knowledge, all oligopyrrole systems with a direct pyrrole-pyrrole linkage that have been synthesized to date

are either $2,2^{\prime}$ - or $3,3^{\prime}$-linked. Systems with mixed linkages, such as $3,3^{\prime}: 2^{\prime}, 2^{\prime \prime}: 3^{\prime \prime}, 3^{\prime \prime}$-linked tetrapyrroles, have not yet been synthesized. Our idea was to couple two bispyrroles under oxidative conditions. We tested various oxidizing agents, such as hypervalent iodine reagents and silver(I) salts. The best oxidant was $\mathrm{AgBF}_{4}$, which afforded the desired tetrapyrrole 16 in a moderate yield of $21 \%$ (Scheme 6 ). Tetramers with more electronrich bispyrroles as starting materials were identified by mass spectrometry, but we were unable to isolate them.

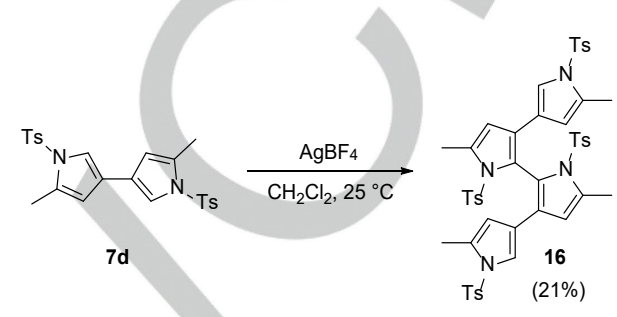

Scheme 6. Oxidative dimerization of 3,3'-linked bispyrrole $7 \mathbf{d}$.

The structure of the diketone-bridged bispyrrole 10a was confirmed by $\mathrm{X}$-ray analysis (Figure 2 , top). The bond length between the two carbonyl carbons (C23-C24; 1.5718(13) $\AA$ ) is much longer than a common $\mathrm{C}-\mathrm{C}$ single bond. Furthermore, the bond length $\mathrm{C} 1-\mathrm{C} 23$ is, at $1.4322(13) \AA$, comparable to the $\mathrm{C}-\mathrm{C}$ single bond length in 1,3-butadiene. The same holds true for the linkage between the pyrrole rings (C4-C-6; 1.4567(13) A). The pyrrole units and the benzene rings are almost perpendicular to each other (interplanar angles $79^{\circ}$ and $87^{\circ}$ ). The structure of the condensation product $\mathbf{1 2 b}$ was also elucidated by X-ray diffraction. Two independent molecules were found in the asymmetric unit. The respective bond lengths in these two molecules are very similar to each other; thus, we depict only one of them in Figure 2 (bottom). Interestingly, the $\mathrm{C}-\mathrm{C}$ bond lengths where the sixmembered rings are annulated (C4-C6; C23-C24; C25-C30; C27-C28) are rather long, ranging from $1.418 \AA$ to $1.457 \AA$ (typical s.u.'s ca. $0.0015 \AA$ ). For the terminal benzene ring, but also for the benzene with the annulated pyrrole units, a strong bond length alternation is observed; C26-C27 and C28-C29 are about $1.37 \AA$ whereas the adjacent bonds $\mathrm{C} 25-\mathrm{C} 26$ and $\mathrm{C} 29-\mathrm{C} 30$ are about $1.42 \AA$. The same holds true for $\mathrm{C} 1-\mathrm{C} 23$ and $\mathrm{C} 5-\mathrm{C} 24$ (about $1.43 \AA$ ) and C1-C4 and C5-C6 (1.395 Å). A similar behavior of bond length alternation is found in anthracene. ${ }^{[23]}$ 

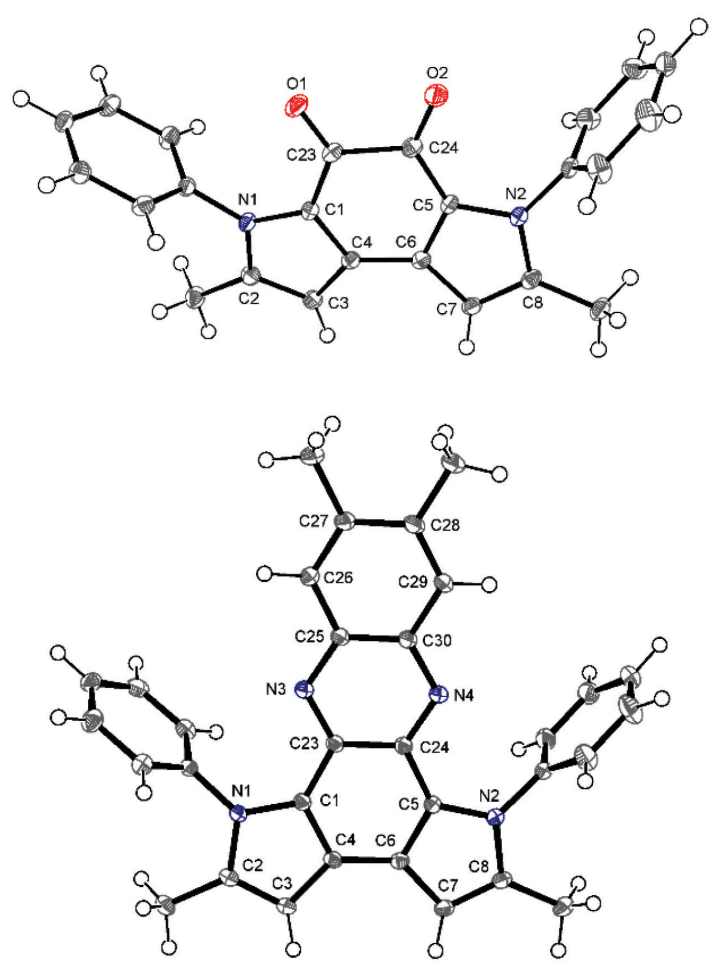

Figure 2. Molecular structures (50\% ellipsoid probability) of 10a (top) and 12b (bottom, one of two independent molecules) in the solid state.

\section{Conclusions}

We have demonstrated a versatile usage of $3,3^{\prime}$-linked bispyrroles in reactions with various carbon electrophiles to access new molecular scaffolds derived from the 3,3'-linked bispyrrole motif. The important factor was the high nucleophilicity of these entities at their 2-position. A diketone bridge was generated by reacting the bispyrrole with oxalyl chloride, and this product then served as the starting material for the extension of the $\pi$-system via condensation with diamines under Lewis acid catalysis. Furthermore, a seven-membered anhydride was obtained by treatment with triphosgene. This capricious species was easily opened to afford diesters. Moreover, the nucleophilic addition of the Vilsmeier reagent led to bisformylated bispyrroles. Under oxidative conditions we were able to prepare for the first time a tetrapyrrole whose subunits are connected in a $3,3^{\prime}: 2^{\prime}, 2^{\prime \prime}: 3^{\prime \prime}, 3^{\prime \prime}-$ fashion.

\section{Experimental Section}

General Methods: All reactions were performed in flame-dried glassware under an argon atmosphere. The solvents were dried by standard procedures. Commercially available compounds were used without further purification unless otherwise stated. ${ }^{1} \mathrm{H}$ and ${ }^{13} \mathrm{C}$ NMR spectra were recorded with a 400,500 or $600 \mathrm{MHz}$ instrument using the residual signals from $\mathrm{CHCl}_{3}(\delta=7.26 \mathrm{ppm}$ and $\delta=77.16 \mathrm{ppm})$. Additionally, tetramethylsilane (TMS; $\delta=0 \mathrm{ppm}, 0.03 \%$ ) was added to NMR samples.
The following abbreviations were used for ${ }^{1} \mathrm{H}$ and ${ }^{13} \mathrm{C}$ chemical shifts: $\mathrm{s}=$ singlet, $d=$ doublet, $\mathrm{t}=$ triplet, $\mathrm{q}=$ quartet, $\mathrm{m}=$ multiplet. ESI-HRMS mass spectrometry was carried out on a FTICR instrument. IR spectra were recorded on an ATR spectrometer Tensor 27 from Bruker. UV spectra were measured with a common photometer. Melting points were determined in open capillary tubes.

\section{General Procedures}

(A) Preparation of 1,2-Diketones: Pyridine (1.2-2.4 equiv.) was added to a mixture of oxalyl chloride ( 1.0 equiv.) in $\mathrm{CH}_{2} \mathrm{Cl}_{2}(75 \mu \mathrm{M})$ at $-78^{\circ} \mathrm{C}$ and the mixture was stirred for $30 \mathrm{~min}$. Then, $3,3^{\prime}$-bispyrrol (1.0 equiv.) was added, with subsequent stirring for $40 \mathrm{~min}$, and hydrochloric acid $(1 \mathrm{~mL})$ was added. After extraction with $\mathrm{CH}_{2} \mathrm{Cl}_{2}(3 \times)$ the combined organic layers were dried over $\mathrm{Na}_{2} \mathrm{SO}_{4}$. Solvents were removed in vacuo. The product was isolated by flash column chromatography on silica gel.

(B) Preparation of Diimines: $\mathrm{BF}_{3} \cdot \mathrm{EtO}_{2}(20 \mathrm{~mol} \%)$ was added to a solution of diketone (1.0 equiv.) and 1,2-diamine (2.0 equiv.) in hexafluoroisopropanol $(0.1 \mathrm{M})$ and the mixture was stirred for $14 \mathrm{~h}$ at $150{ }^{\circ} \mathrm{C}$ in the microwave oven. Solvents were removed in vacuo and the product was isolated by flash column chromatography on silica gel.

Diketone 10a: Synthesized by using General Procedure A from bispyrrole 7b $(480 \mathrm{mg}, 1.53 \mathrm{mmol}, 1.0$ eqiuv.), pyridine $(0.30 \mathrm{~mL}, 3.67 \mathrm{mmol}$, 2.4 equiv.) and oxalyl chloride $(0.13 \mathrm{~mL}, 1.53 \mathrm{mmol}, 1.0$ equiv.). Purification: Flash column chromatography $\left(\mathrm{SiO}_{2}\right.$; pentane/EtOAc, $\left.2: 1\right)$, yield $448 \mathrm{mg}(1.22 \mathrm{mmol}, 83 \%)$; red solid. ${ }^{1} \mathrm{H}-\mathrm{NMR}\left(600 \mathrm{MHz}, \mathrm{CDCl}_{3}\right): \delta=$ $2.06(\mathrm{~s}, 6 \mathrm{H}), 6.14(\mathrm{~s}, 2 \mathrm{H}), 7.22(\mathrm{~m}, 4 \mathrm{H}), 7.43(\mathrm{~m}, 6 \mathrm{H}) \mathrm{ppm} .{ }^{13} \mathrm{C}-\mathrm{NMR}$ $\left(150 \mathrm{MHz}, \mathrm{CDCl}_{3}\right): \delta=12.9,105.9,125.8,127.1,128.6,129.0,129.4$, 137.3, 142.0, 169.0 ppm. m.p.: >250 ${ }^{\circ} \mathrm{C}$. IR (ATR): $v\left(\mathrm{~cm}^{-1}\right)=3109,2853$, $1629,1596,1479,1453,1326$. UV $\left(\mathrm{CH}_{3} \mathrm{CN}\right): \lambda_{\max }\left[\lg \left(\varepsilon / \mathrm{M}^{-1} \mathrm{~cm}^{-1}\right)\right]=369 \mathrm{~nm}$ (4.22), 256 (4.23), 217 (4.53). HRMS (ESI): calcd. for $\mathrm{C}_{24} \mathrm{H}_{18} \mathrm{~N}_{2} \mathrm{O}_{2}[\mathrm{M}+\mathrm{H}]^{+}$ 367.14410 ; found 367.14418 .

Diketone 10b: Synthesized by using General Procedure A from bispyrrole $7 \mathrm{a}$ (50 mg, $0.13 \mathrm{mmol}, 1.0$ eqiuv.), pyridine ( $13 \mu \mathrm{L}, 0.16 \mathrm{mmol}, 1.2$ equiv.) and oxalyl chloride $(11 \mu \mathrm{L}, 0.13 \mathrm{mmol}, 1.0$ equiv.). Purification: Flash column chromatography $\left(\mathrm{SiO}_{2}\right.$; pentane/EtOAc, $\left.2: 1\right)$, yield $30.0 \mathrm{mg}$ (0.07 mmol, 55\%); orange solid. ${ }^{1} \mathrm{H}-\mathrm{NMR}\left(600 \mathrm{MHz}, \mathrm{CDCl}_{3}\right): \delta=2.05(\mathrm{~s}$, $6 \mathrm{H}), 3.84(\mathrm{~s}, 6 \mathrm{H}), 6.11(\mathrm{~s}, 2 \mathrm{H}), 6.93-6.95(\mathrm{~m}, 4 \mathrm{H}), 7.12-7.15(\mathrm{~m}, 4 \mathrm{H})$ ppm. ${ }^{13} \mathrm{C}-\mathrm{NMR}\left(150 \mathrm{MHz}, \mathrm{CDCl}_{3}\right): \delta=12.6,55.2,105.5,114.03,125.7$, $127.9,129.1,129.9,142.1,159.2,168.9$ ppm. m.p.: $>250{ }^{\circ} \mathrm{C}$. IR (ATR): $v\left(\mathrm{~cm}^{-1}\right)=3094,3012,2920,2832,1626,1607,1511,1244,1031$. UV $\left(\mathrm{CH}_{3} \mathrm{CN}\right): \lambda_{\max }\left[\mathrm{lg}\left(\varepsilon / \mathrm{M}^{-1} \mathrm{~cm}^{-1}\right)\right]=371 \mathrm{~nm}$ (4.07), 228 (4.54), 193 (4.83). HRMS (ESI): calcd. for $\mathrm{C}_{26} \mathrm{H}_{22} \mathrm{~N}_{2} \mathrm{O}_{4}[\mathrm{M}+\mathrm{Na}]^{+} 449.14718$; found 449.14742.

Diketone 10c: Synthesized by using General Procedure A from bispyrrole 7c (40 mg, $0.12 \mathrm{mmol}, 1.0$ eqiuv.), pyridine ( $23 \mu \mathrm{L}, 0.28 \mathrm{mmol}, 2.4$ equiv.) and oxalyl chloride ( $10 \mu \mathrm{L}, 0.12 \mathrm{mmol}, 1.0$ equiv.). Purification: Flash column chromatography $\left(\mathrm{SiO}_{2}\right.$; pentane/EtOAc, $\left.1: 1\right)$, yield $32.0 \mathrm{mg}$ (0.08 mmol, $68 \%)$; red solid. ${ }^{1} \mathrm{H}-\mathrm{NMR}\left(400 \mathrm{MHz}, \mathrm{CDCl}_{3}\right): \delta=1.96(\mathrm{~s}, 6 \mathrm{H})$, 2.35 (s, $6 \mathrm{H}), 7.16-7.19$ (m, $4 \mathrm{H}), 7.37-7.44$ (m, $6 \mathrm{H})$ ppm. ${ }^{13} \mathrm{C}-\mathrm{NMR}(100$ $\left.\mathrm{MHz}, \mathrm{CDCl}_{3}\right): \delta=10.9,13.5,114.5,126.2,127.2,128.4,128.4,129.0$, 138.2, 140.3, 169.1 ppm. m.p.: $175^{\circ} \mathrm{C}$. IR (ATR): $v\left(\mathrm{~cm}^{-1}\right)=2918,2852$, 1636, 1494, 1417, 1323, 1155, 1077. UV $\left(\mathrm{CH}_{3} \mathrm{CN}\right): \lambda_{\max }[\mathrm{lg}$ $\left.\left(\varepsilon / \mathrm{M}^{-1} \mathrm{~cm}^{-1}\right)\right]=393 \mathrm{~nm}$ (4.07), 216 (4.43). HRMS (ESI): calcd. for $\mathrm{C}_{26} \mathrm{H}_{22} \mathrm{~N}_{2} \mathrm{O}_{2}[\mathrm{M}+\mathrm{Na}]^{+}$417.15735; found 417.15746.

Diimine 12a: Synthesized by using General Procedure B from diketone 10a (20 mg, $50 \mu \mathrm{mol}, 1.0$ equiv.) and benzene-1,2-diamine (10.8 mg, $100 \mu \mathrm{mol}, 2.0$ equiv.). Purification: flash column chromatography $\left(\mathrm{SiO}_{2}\right.$; pentane/EtOAc, 40:1), yield $5.1 \mathrm{mg}(12 \mu \mathrm{mol}, 24 \%)$, yellow solid. ${ }^{1} \mathrm{H}-\mathrm{NMR}$ 
$\left(500 \mathrm{MHz}, \mathrm{CDCl}_{3}\right): \delta=2.28(\mathrm{~d}, J=0.8 \mathrm{~Hz}, 6 \mathrm{H}), 6.65(\mathrm{~s}, 1 \mathrm{H}), 6.65(\mathrm{~s}, 1 \mathrm{H})$, $7.25-7.28(\mathrm{~m}, 2 \mathrm{H}), 7.29-7.33(\mathrm{~m}, 2 \mathrm{H}), 7.34-7.38(\mathrm{~m}, 4 \mathrm{H}), 7.46-7.49$ $(\mathrm{m}, 6 \mathrm{H}) \mathrm{ppm} .{ }^{13} \mathrm{C}-\mathrm{NMR}\left(126 \mathrm{MHz}, \mathrm{CDCl}_{3}\right): \delta=13.5,101.9,122.7,124.7$, $126.9,127.7,128.6,128.6,128.9,134.6,138.2,138.4,140.7 \mathrm{ppm}$. IR (ATR): $v\left(\mathrm{~cm}^{-1}\right)=2919,2851,1591,1492,1445,1323,1125$. UV $\left(\mathrm{CH}_{3} \mathrm{CN}\right)$ : $\lambda_{\max }\left[\mathrm{lg}\left(\varepsilon / \mathrm{M}^{-1} \mathrm{~cm}^{-1}\right)\right]=438 \mathrm{~nm}$ (4.01), 309 (4.64). HRMS (ESI): calcd. for $\mathrm{C}_{30} \mathrm{H}_{22} \mathrm{~N}_{4}[\mathrm{M}+\mathrm{Na}]^{+} 461.17367$; found 461.17391 .

Diimine 12b: Synthesized by using General Procedure B from diketone 10a $(20 \mathrm{mg}, 50 \mu \mathrm{mol}, 1.0$ equiv.) and 4,5-dimethylbenzene-1,2-diamine (13.6 mg, $100 \mu \mathrm{mol}, \quad 2.0$ equiv.). Purification: Flash column chromatography $\left(\mathrm{SiO}_{2}\right.$; pentane/EtOAc, $\left.40: 1\right)$, yield $17.9 \mathrm{mg}(38 \mu \mathrm{mol}$, $77 \%)$, yellow solid. ${ }^{1} \mathrm{H}-\mathrm{NMR}\left(400 \mathrm{MHz}, \mathrm{CDCl}_{3}\right): \delta=2.31(\mathrm{~s}, 6 \mathrm{H}), 2.32(\mathrm{~d}$ $J=0.7 \mathrm{~Hz}, 6 \mathrm{H}), 6.69(\mathrm{~d}, J=0.8 \mathrm{~Hz}, 2 \mathrm{H}), 7.07(\mathrm{~d}, J=0.9 \mathrm{~Hz}, 2 \mathrm{H}), 7.39$ $7.45(\mathrm{~m}, 4 \mathrm{H}), 7.51-7.56(\mathrm{~m}, 6 \mathrm{H}) \mathrm{ppm} .{ }^{13} \mathrm{C}-\mathrm{NMR}\left(100 \mathrm{MHz}, \mathrm{CDCl}_{3}\right): \delta=$ $13.5,20.1,101.7,122.1,124.9,127.5,127.6,128.6,128.9,134.1,137.4$ 137.5, 137.7, 140.9 ppm. m.p.: $221^{\circ} \mathrm{C}$. IR (ATR): $v\left(\mathrm{~cm}^{-1}\right)=3060,3034$, $2965,2920,2851,1593,1534,1497,1442,1418,1321$. UV $\left(\mathrm{CH}_{3} \mathrm{CN}\right): \lambda_{\max }$ $\left[\lg \left(\varepsilon / \mathrm{M}^{-1} \mathrm{~cm}^{-1}\right)\right]=438 \mathrm{~nm}(4.16), 309$ (4.76), 241 (4.35), 191 (4.72). HRMS (ESI): calcd. for $\mathrm{C}_{34} \mathrm{H}_{30} \mathrm{~N}_{4}[\mathrm{M}+\mathrm{H}]^{+} 467.22302$; found 467.22312 .

Diimine 12c: Synthesized by using General Procedure B from diketone 10c $(20 \mathrm{mg}, 50 \mu \mathrm{mol}, 1.0$ equiv.) and 4,5-dimethylbenzene-1,2-diamine (13.6 mg, $100 \mu \mathrm{mol}, \quad 2.0$ equiv.). Purification: Flash column chromatography $\left(\mathrm{SiO}_{2}\right.$; pentane/EtOAc, $\left.50: 1\right)$, yield $10.6 \mathrm{mg}(21 \mu \mathrm{mol}$, $43 \%$ ), yellow solid. ${ }^{1} \mathrm{H}-\mathrm{NMR}\left(500 \mathrm{MHz}, \mathrm{CDCl}_{3}\right): \delta=2.25(\mathrm{~s}, 6 \mathrm{H}), 2.29(\mathrm{~s}$, $6 \mathrm{H}), 2.71(\mathrm{~s}, 6 \mathrm{H}), 6.97(\mathrm{~s}, 2 \mathrm{H}), 7.34-7.38(\mathrm{~m}, 4 \mathrm{H}), 7.50-7.54(\mathrm{~m}, 6 \mathrm{H})$ ppm. ${ }^{13} \mathrm{C}-\mathrm{NMR}\left(126 \mathrm{MHz}, \mathrm{CDCl}_{3}\right): \delta=11.3,14.3,20.2,109.6,122.0,124.9$ 127.4, 127.4, 128.6, 129.0, 133.8, 134.7, 137.2, 137.7, 141.9 ppm. m.p.: $>250^{\circ} \mathrm{C}$. IR (ATR): $v\left(\mathrm{~cm}^{-1}\right)=2917,2852,1597,1521,1444,1416,1331$ 1188. UV $\left(\mathrm{CH}_{3} \mathrm{CN}\right): \lambda_{\max }\left[\mathrm{lg}\left(\varepsilon / \mathrm{M}^{-1} \mathrm{~cm}^{-1}\right)\right]=454 \mathrm{~nm}(4.16), 314$ (4.69), 260 (4.34). HRMS (ESI): calcd. for $\mathrm{C}_{32} \mathrm{H}_{26} \mathrm{~N}_{4}[\mathrm{M}+\mathrm{H}]^{+}$495.25432; found 495.25397.

Diester 14: Triphosgene (58 mg, $0.20 \mathrm{mmol}, 1.5$ equiv.) was added to a solution of $3,3^{\prime}$-bispyrrole $7 \mathrm{~b}(40 \mathrm{mg}, 0.13 \mathrm{mmol}, 1.0$ equiv.) in toluene $(1.5 \mathrm{~mL})$ and the mixture was stirred for $20 \mathrm{~h}$ at $40^{\circ} \mathrm{C} . \mathrm{H}_{2} \mathrm{O}(5 \mathrm{~mL})$ was added, and aqueous layer was extracted with $\mathrm{CH}_{2} \mathrm{Cl}_{2}(3 \times)$; the combined organic layers were dried over $\mathrm{Na}_{2} \mathrm{SO}_{4}$ followed by the removal of the solvents in vacuo. The residue was dissolved in $\mathrm{MeOH}(1.5 \mathrm{~mL})$ and $\mathrm{NaBH}_{4}(7.57 \mathrm{mg}, 0.20 \mathrm{mmol})$ was added at $0{ }^{\circ} \mathrm{C}$ and the mixture warmed up to rt. The solvents were removed in vacuo. The crude product was purified by flash column chromatography $\left(\mathrm{SiO}_{2}, n\right.$-pentane: EtOAc $\left.=4: 1\right)$, yield $28 \mathrm{mg}(0.07 \mathrm{mmol}, 53 \%)$; colorless solid. ${ }^{1} \mathrm{H}-\mathrm{NMR}(400 \mathrm{MHz}$, $\left.\mathrm{CDCl}_{3}\right): \delta=2.05(\mathrm{~d}, J=0.8 \mathrm{~Hz}, 6 \mathrm{H}), 3.46(\mathrm{~s}, 6 \mathrm{H}), 6.13(\mathrm{~d}, J=1.0 \mathrm{~Hz}, 2 \mathrm{H})$ 7.23-7.28 (m, $4 \mathrm{H}), 7.39-7.50(\mathrm{~m}, 6 \mathrm{H}) .{ }^{13} \mathrm{C}-\mathrm{NMR}\left(100 \mathrm{MHz}, \mathrm{CDCl}_{3}\right): \delta=$ $12.9,50.7,111.1,120.5,126.8,127.8,127.9,128.7,135.6,139.8,161.6$ ppm. m.p.: $144{ }^{\circ} \mathrm{C}$. IR (ATR): $v\left(\mathrm{~cm}^{-1}\right)=3060,2952,2922,1697,1595$, $1494,1441,1403,1273,1160,1084$. UV $\left(\mathrm{CH}_{3} \mathrm{CN}\right): \lambda_{\max }[\mathrm{lg}$ $\left.\left(\varepsilon / \mathrm{M}^{-1} \mathrm{~cm}^{-1}\right)\right]=261 \mathrm{~nm} \quad(4.36), 195 \quad$ (4.68). HRMS (ESI): calcd. for $\mathrm{C}_{26} \mathrm{H}_{24} \mathrm{~N}_{2} \mathrm{O}_{4}[\mathrm{M}+\mathrm{Na}]^{+}$451.16283; found 451.16314.

Dialdehyde 15a: $\mathrm{POCl}_{3}(22 \mu \mathrm{L}, 0.24 \mathrm{mmol}, 2.0$ equiv. $)$ and DMF $(22 \mu \mathrm{L}$, $0.24 \mathrm{mmol}, 2.0$ equiv.) were stirred for $10 \mathrm{~min}$ at $0{ }^{\circ} \mathrm{C}$, a solution of $3,3-$ bispyrrole $7 \mathrm{a}$ ( $60 \mathrm{mg}, 0.16 \mathrm{mmol}, 1.3$ equiv.) in 1,2-dichloroethane $(1 \mathrm{~mL})$ was added and the mixture was stirred for $20 \mathrm{~min}$ at $90^{\circ} \mathrm{C}$. At $0{ }^{\circ} \mathrm{C}$ a solution of $\mathrm{NaOAc}(109 \mathrm{mg}, 0.80 \mathrm{mmol})$ in $\mathrm{H}_{2} \mathrm{O}(5 \mathrm{~mL})$ was added the mixture stirred for a further $20 \mathrm{~min}$ at $90^{\circ} \mathrm{C}$. After extraction with $\mathrm{CH}_{2} \mathrm{Cl}_{2}$ $(3 \times 10 \mathrm{~mL})$, the combined organic layers were washed with $\mathrm{NaHCO}_{3}$ solution $\left(20 \mathrm{~mL}\right.$ ) and were dried over $\mathrm{Na}_{2} \mathrm{SO}_{4}$ followed by the removal of the solvents in vacuo. The crude product was purified by flash column chromatography $\left(\mathrm{SiO}_{2}, n\right.$-pentane:EtOAc $\left.=4: 1\right)$, yield $28 \mathrm{mg}(0.07 \mathrm{mmol}$, $58 \%$ ); yellow solid. ${ }^{1} \mathrm{H}-\mathrm{NMR}\left(600 \mathrm{MHz}, \mathrm{CDCl}_{3}\right): \delta=2.09(\mathrm{~s}, 6 \mathrm{H}), 3.87(\mathrm{~s}$, $6 \mathrm{H}), 6.26(\mathrm{~s}, 2 \mathrm{H}), 6.98-7.01(\mathrm{~m}, 4 \mathrm{H}), 7.20-7.22(\mathrm{~m}, 4 \mathrm{H}), 9.54(\mathrm{~s}, 2 \mathrm{H})$.
${ }^{13} \mathrm{C}-\mathrm{NMR}\left(150 \mathrm{MHz}, \mathrm{CDCl}_{3}\right): \delta=12.3,55.2,112.4,114.0,128.3,129.4$ 129.5, 130.5, 139.1, 159.2, 178.27 ppm. m.p.: $200^{\circ} \mathrm{C}$. IR (ATR): v (cm 1) $=$ 2919, 2832, 2806, 1645, 1511, 1449, 1412, 1335, 1296, 1248, 1031. UV $\left(\mathrm{CH}_{3} \mathrm{CN}\right): \lambda_{\max }\left[\mathrm{lg}\left(\varepsilon / \mathrm{M}^{-1} \mathrm{~cm}^{-1}\right)\right]=298 \mathrm{~nm}(4.40), 284$ (4.43), 225 (4.49), 193 (4.93). HRMS (ESI): calcd. for $\mathrm{C}_{26} \mathrm{H}_{24} \mathrm{~N}_{2} \mathrm{O}_{4}[\mathrm{M}+\mathrm{Na}]^{+} 451.16283$; found 451.16316 .

Aldehyde 15b: $\mathrm{POCl}_{3}(25 \mu \mathrm{L}, 0.27 \mathrm{mmol}, 2.0$ equiv. $)$ and DMF $(28 \mu \mathrm{L}$, $0.36 \mathrm{mmol}, 2.8$ equiv.) were stirred for $10 \mathrm{~min}$, a solution of $3,3^{\prime}$-bispyrrole $7 \mathrm{~b}$ (40 mg, $0.13 \mathrm{mmol}, 1.0$ equiv.) in $\mathrm{CH}_{2} \mathrm{Cl}_{2}(1.5 \mathrm{~mL})$ was added and the mixture was stirred for $1 \mathrm{~h}$ at $50^{\circ} \mathrm{C}$. Water $(5 \mathrm{~mL})$ and a $\mathrm{NaOH}$ solution (20 wt\%, $3 \mathrm{~mL}$ ) were added at $25^{\circ} \mathrm{C}$ and stirring continued for $10 \mathrm{~min}$ at $90^{\circ} \mathrm{C}$. After extraction with $\mathrm{CH}_{2} \mathrm{Cl}_{2}(3 \times 10 \mathrm{~mL})$ the combined organic layers were dried over $\mathrm{Na}_{2} \mathrm{SO}_{4}$ followed by the removal of the solvents in vacuo. The crude product was purified by flash column chromatography $\left(\mathrm{SiO}_{2}, n\right.$-pentane:EtOAc $\left.=3: 1\right)$, yield $36 \mathrm{mg}(0.10 \mathrm{mmol}, 77 \%)$; yellow solid. ${ }^{1} \mathrm{H}-\mathrm{NMR}\left(400 \mathrm{MHz}, \mathrm{CDCl}_{3}\right): \delta=2.10(\mathrm{~s}, 6 \mathrm{H}), 6.29(\mathrm{~d}, J=0.8 \mathrm{~Hz}$ $2 \mathrm{H}), 7.28-7.32(\mathrm{~m}, 4 \mathrm{H}), 7.46-7.52(\mathrm{~m}, 6 \mathrm{H}), 9.56$ (s, $2 \mathrm{H}) .{ }^{13} \mathrm{C}-\mathrm{NMR}(100$ $\left.\mathrm{MHz}, \mathrm{CDCl}_{3}\right): \delta=12.5,112.8,127.6,128.5,129.0,129.5,129.8,138.1$ 139.0, 178.3 ppm. m.p.: $179^{\circ} \mathrm{C}$. IR (ATR): $v\left(\mathrm{~cm}^{-1}\right)=3114,2920,2842$, $1655,1635,1494,1475,1407,1336,1312,1249$. UV $\left(\mathrm{CH}_{3} \mathrm{CN}\right): \lambda_{\max }[\mathrm{lg}$ $\left.\left(\varepsilon / \mathrm{M}^{-1} \mathrm{~cm}^{-1}\right)\right]=297 \mathrm{~nm}$ (4.36), 286 (4.37), 193 (4.71). HRMS (ESI): calcd. for $\mathrm{C}_{24} \mathrm{H}_{20} \mathrm{~N}_{2} \mathrm{O}_{2}[\mathrm{M}+\mathrm{Na}]^{+}$391.14170; found 391.14215.

Tetrapyrrole 16: $\mathrm{AgBF}_{4}(17 \mathrm{mg}, 0.08 \mathrm{mmol})$ was added to a solution of $3,3^{\prime}$-bispyrrole $7 \mathrm{~d}(20 \mathrm{mg}, 0.04 \mathrm{mmol})$ and the mixture was stirred for $22 \mathrm{~h}$ at room temperature. The solvents were removed in vacuo and purification by silica gel column chromatography $(n$-pentane:EtOAc $=2: 1$ ) yielded the desired compound ( $28 \mathrm{mg}, 0.07 \mathrm{mmol}, 41 \%$ ) as white solid. The crude product was purified by flash column chromatography $\left(\mathrm{SiO}_{2}\right.$ $n$-pentane:EtOAc $=2: 1)$, yield $4.0 \mathrm{mg}(4.3 \mu \mathrm{mol}, 21 \%)$; colorless solid. ${ }^{1} \mathrm{H}-\mathrm{NMR}\left(600 \mathrm{MHz}, \mathrm{CDCl}_{3}\right): \delta=2.09(\mathrm{~d}, \mathrm{~J}=0.8 \mathrm{~Hz}, 6 \mathrm{H}), 2.25(\mathrm{~s}, 6 \mathrm{H})$ $2.27(\mathrm{~s}, 6 \mathrm{H}), 2.56(\mathrm{~d}, J=1.0 \mathrm{~Hz}, 6 \mathrm{H}), 5.56(\mathrm{dd}, J=1.9,1.1 \mathrm{~Hz}, 2 \mathrm{H}), 6.24$ $(\mathrm{d}, J=1.1 \mathrm{~Hz}, 2 \mathrm{H}), 6.75(\mathrm{~d}, J=1.9 \mathrm{~Hz}, 2 \mathrm{H}), 6.83-6.89(\mathrm{~m}, 4 \mathrm{H}), 7.39$ $7.41(\mathrm{~m}, 8 \mathrm{H}) .{ }^{13} \mathrm{C}-\mathrm{NMR}\left(150 \mathrm{MHz}, \mathrm{CDCl}_{3}\right): \delta=13.2,15.6,21.2,21.3$ $110.8,112.1,118.2,119.2,119.4,122.7,126.5,127.2,128.9,129.6,129.8$, 133.8, 135.7, 136.3, 143.9, $144.3 \mathrm{ppm}$. IR (ATR): $v\left(\mathrm{~cm}^{-1}\right)=2924,2853$, $1719,1595,1494,1446,1360,1169,1148,1092$. UV $\left(\mathrm{CH}_{3} \mathrm{CN}\right): \lambda_{\max }[\mathrm{lg}$ $\left.\left(\varepsilon / \mathrm{M}^{-1} \mathrm{~cm}^{-1}\right)\right]=227 \mathrm{~nm} \quad$ (4.65), $194 \quad(5.05)$. HRMS (ESI): calcd. for $\mathrm{C}_{48} \mathrm{H}_{46} \mathrm{~N}_{4} \mathrm{O}_{8} \mathrm{~S}_{4}[\mathrm{M}+\mathrm{Na}]^{+}$957.20907; found 957.20963.

\section{Crystal Structure Determinations}

Crystals were mounted in inert oil on glass fibres and transferred to the cold gas stream of the diffractometer (Oxford Diffraction Xcalibur E with monochromated Mo $\mathrm{K} \alpha$ radiation). Absorption corrections were implemented on the basis of multi-scans. The structures were refined anisotropically on $F^{2}$ using the program SHELXL-97. ${ }^{[24]}$ Hydrogens were refined using rigid methyl groups or a riding model starting from calculated positions. Special features: For compound 10a, optical examination of the prismatic crystals showed that they were non-merohedrally twinned, generally with two components joined along an axis parallel to the prism direction. Attempts to remove a twin component by cutting seemed to have been successful, but an analysis of the data showed that a small amount of a twin component was still present, generated by rotation of $180^{\circ}$ about the $a$ axis. Data were reduced to produce an intensity file in "HKLF 5" format. This method merges equivalent reflections (except for overlaps); the number of reflections and the $\mathrm{R}$ (int) value are thus not meaningful. The relative volume of the smaller twin component refined to $4.21(5) \%$.

Crystallographic data are summarized in the Supporting Information (Table S1). Additionally, complete data have been deposited with the Cambridge Crystallographic Data Centre under the numbers CCDC 1891779 and 1891780 . Copies of the data can be obtained free of charge from www.ccdc.cam.ac.uk/data_request/cif. 


\section{Acknowledgments}

This Research was supported by the European Research Council (ERC Consolidator Grant "GAINBYSTRAIN" to D.B.W).

Keywords: pyrrole $\cdot$ heterocycles $\bullet$ bispyrroles $\bullet$ aromatic systems $\bullet$ donor-acceptor cyclopropanes

[1] a) O. Hayaishi, M. Katagiri, S. Rothberg, J. Am. Chem. Soc. 1955, 77 , 5450; b) H. S. Mason, W. L. Fowlks, E. Peterson, J. Am. Chem. Soc. 1955, 77, 2914; c) T. L. Poulos, Chem. Rev. 2014, 114, 3919.

[2] I. Fleming, Nature 1967, 216, 151

[3] R. Bonnett, J. R. Cannon, V. M. Clark, A. W. Johnson, L. F. J. Parker, E. L. Smith, A. Todd, J. Chem. Soc. 1957, 1158.

[4] K. Dairi, S. Tripathy, G. Attardo, J.-F. Lavallée, Tetrahedron Lett. 2006, 47, 2605.

[5] a) B. Jolicoeur, W. D. Lubell, Org. Lett. 2006, 8, 6107; b) L. Fu, G. W. Gribble, Tetrahedron Lett. 2008, 49, 7352.

[6] a) A. López-Pérez, R. Robles-Machín, J. Adrio, J. C. Carretero, Angew. Chem. Int. Ed. 2007, 46, 9261; b) R. Robles-Machín, A. López-Pérez, M. González-Esguevillas, J. Adrio, J. C. Carretero, Chem. Eur. J. 2010, 16, 9864.

[7] a) H. Ikeda, J. L. Sessler, J. Org. Chem. 1993, 58, 2340; b) A. Merz, S. Anikin, B. Lieser, J. Heinze, H. John, Chem. Eur. J. 2003, 9, 449.

[8] D. Sánchez-García, J. I. Borrell, S. Nonell, Org. Lett. 2009, 11, 77

[9] a) M. C. de Jesus, Y. Fu, R. A. Weiss, Polym. Eng. Sci. 1997, 37, 1936; b) B. M. Rambo, J. L. Sessler, Chem. Eur. J. 2011, 17, 4946.

[10] H. Hopf, M. S. Sherburn, Angew. Chem. Int. Ed. 2012, 51, 2298.

[11] R. Gleiter, J. Ritter, Tetrahedron 1996, 52, 10383.

[12] H. Uno, Y. Kitawaki, N. Ono, Chem. Commun. 2002, 116.

[13] B. A. Trofimov, A. B. Zaitsev, E. Y. Schmidt, A. M. Vasil'tsov, A.'b. I. Mikhaleva, I.' A. Ushakov, A. V. Vashchenko, N. V. Zorina, Tetrahedron Lett. 2004, 45, 3789.

[14] a) H. H. Wasserman, V. M. Rotello, R. Frechette, R. W. DeSimone, J. U. Yoo, C. M. Baldino, Tetrahedron 1997, 53, 8731; b) T. Yin, R. Hua, Chem. Lett. 2013, 42, 836

[15] S. Dey, C. Pal, D. Nandi, V. S. Giri, M. Zaidlewicz, M. Krzeminski, L. Smentek, B. A. Hess, J. Gawronski, M. Kwit et al., Org. Lett. 2008, 10, 1373.

[16] Z. Qi, Y. Jiang, B. Yuan, Y. Niu, R. Yan, Org. Lett. 2018, 20, 5048.

[17] P. Magnus, W. Danikiewicz, T. Katoh, J. C. Huffman, K. Folting, J. Am. Chem. Soc. 1990, 112, 2465.

[18] a) J. Kaschel, T. F. Schneider, D. Kratzert, D. Stalke, D. B. Werz, Angew. Chem. Int. Ed. 2012, 51, 11153; b) J. Kaschel, T. F. Schneider, D. Kratzert, D. Stalke, D. B. Werz, Org. Biomol. Chem. 2013, 11, 3494.

[19] a) H.-U. Reissig, R. Zimmer, Chem. Rev. 2003, 103, 1151; b) M. Yu, B. L. Pagenkopf, Tetrahedron 2005, 61, 321; c) C. A. Carson, M. A. Kerr, Chem. Soc. Rev. 2009, 38, 3051; d) F. De Simone, J. Waser, Synthesis 2009, 2009, 3353; e) M. A. Cavitt, L. H. Phun, S. France, Chem. Soc. Rev. 2014, 43, 804; f) T. F. Schneider, J. Kaschel, D. B. Werz, Angew. Chem. Int. Ed. 2014, 53, 5504; g) H. K. Grover, M. R. Emmett, M. A. Kerr, Org. Biomol. Chem. 2015, 13, 655; h) R. A. Novikov, Y. V. Tomilov, Mendeleev Commun. 2015, 25, 1; i) O. Reiser, Isr. J. Chem. 2016, 56, 531.

[20] a) C. Brand, G. Rauch, M. Zanoni, B. Dittrich, D. B. Werz, J. Org. Chem. 2009, 74, 8779; b) S. J. Gharpure, M. K. Shukla, U. Vijayasree, Org. Lett. 2009, 11, 5466; c) T. F. Schneider, J. Kaschel, B. Dittrich, D. B. Werz, Org. Lett. 2009, 11, 2317; d) T. F. Schneider, J. Kaschel, S. I. Awan, B.
Dittrich, D. B. Werz, Chem. Eur. J. 2010, 16, 11276; e) T. F. Schneider, D. B. Werz, Org. Lett. 2011, 13, 1848; f) J. Kaschel, C. D. Schmidt, M. Mumby, D. Kratzert, D. Stalke, D. B. Werz, Chem. Comm. 2013, 49 $4403 ;$ g) C. D. Schmidt, J. Kaschel, T. F. Schneider, D. Kratzert, D. Stalke, D. B. Werz, Org. Lett. 2013, 15, 6098; h) A. Ortega, R. Manzano, U. Uria, L. Carrillo, E. Reyes, T. Tejero, P. Merino, J. L. Vicario, Angew. Chem. Int. Ed. 2018, 57, 8225.

[21] a) F. Benfatti, F. de Nanteuil, J. Waser, Chem. Eur. J. 2012, 18, 4844; b) A. F. G. Goldberg, N. R. O'Connor, R. A. Craig, B. M. Stoltz, Org. Lett. 2012, 14, 5314; c) S. Chakrabarty, I. Chatterjee, B. Wibbeling, C. G. Daniliuc, A. Studer, Angew. Chem. 2014, 126, 6074; d) S. Racine, F. de Nanteuil, E. Serrano, J. Waser, Angew. Chem. Int. Ed. 2014, 53, 8484 e) H.-H. Zhang, Y.-C. Luo, H.-P. Wang, W. Chen, P.-F. Xu, Org. Lett. 2014, 16, 4896; f) C. M. Braun, E. A. Congdon, K. A. Nolin, J. Org. Chem. 2015, 80, 1979; g) Y. Xia, X. Liu, H. Zheng, L. Lin, X. Feng, Angew. Chem. Int. Ed. 2015, 54, 227; h) T. Chidley, N. Vemula, C. A. Carson, M. A. Kerr, B. L. Pagenkopf, Org. Lett. 2016, 18, 2922; i) J. E. Curiel Tejeda, L. C. Irwin, M. A. Kerr, Org. Lett. 2016, 18, 4738; j) L. K. B. Garve, M. Pawliczek, J. Wallbaum, P. G. Jones, D. B. Werz, Chem. Eur. J. 2016, 22, 521; k) L. K. B. Garve, M. Petzold, P. G. Jones, D. B. Werz, Org. Lett. 2016, 18, 564; I) A. Ghosh, S. Mandal, P. K. Chattaraj, P. Banerjee, Org. Lett. 2016 , 18, 4940; m) J. Sabbatani, N. Maulide, Angew. Chem. Int. Ed. 2016, 55, 6780; n) D.-C. Wang, M.-S. Xie, H.-M. Guo, G.-R. Qu, M.-C. Zhang, S.L. You, Angew. Chem. Int. Ed. 2016, 55, 14111; o) Y. Xia, L. Lin, F. Chang, Y. Liao, X. Liu, X. Feng, Angew. Chem. Int. Ed. 2016, 55, 12228; p) A. U. Augustin, M. Sensse, P. G. Jones, D. B. Werz, Angew. Chem. Int. Ed. 2017, 56, 14293; q) L. K. B. Garve, P. G. Jones, D. B. Werz, Angew. Chem. Int. Ed. 2017, 56, 9226; r) L. K. B. Garve, A. Kreft, P. G. Jones, D. B. Werz, J. Org. Chem. 2017, 82, 9235; s) K. Mondal, S. C. Pan, Eur. J. Org. Chem. 2017, 534; t) J. Preindl, S. Chakrabarty, J. Waser, Chem. Sci. 2017, 8, 7112; u) Z. Su, S. Qian, S. Xue, C. Wang, Org. Biomol. Chem. 2017, 15, 7878; v) Z.-H. Wang, H.-H. Zhang, D.-M. Wang, P.-F. Xu, Y.C. Luo, Chem. Comm. 2017, 53, 8521; w) A. U. Augustin, M. Busse, P. G. Jones, D. B. Werz, Org. Lett. 2018, 20, 820; x) A. O. Chagarovskiy, V. S. Vasin, V. V. Kuznetsov, O. A. Ivanova, V. B. Rybakov, A. N. Shumsky N. N. Makhova, I. V. Trushkov, Angew. Chem. Int. Ed. 2018, 57, 10338; y) A. Kreft, P. G. Jones, D. B. Werz, Org. Lett. 2018, 20, 2059; z) Y Matsumoto, D. Nakatake, R. Yazaki, T. Ohshima, Chem. Eur. J. 2018, 24 , 6062.

[22] a) W. Zhu, J. Fang, Y. Liu, J. Ren, Z. Wang, Angew. Chem. Int. Ed. 2013, 52, 2032; b) W. D. Mackay, M. Fistikci, R. M. Carris, J. S. Johnson, Org Lett. 2014, 16, 1626; c) R. A. Novikov, A. V. Tarasova, V. A. Korolev, V. P. Timofeev, Y. V. Tomilov, Angew. Chem. Int. Ed. 2014, 53, 3187; d) J. Zhu, Y. Liang, L. Wang, Z.-B. Zheng, K. N. Houk, Y. Tang, J. Am. Chem. Soc. 2014, 136, 6900; e) R. A. Novikov, A. V. Tarasova, V. A. Korolev, E. V. Shulishov, V. P. Timofeev, Y. V. Tomilov, J. Org. Chem. 2015, 80, 8225; f) H. Xu, J.-L. Hu, L. Wang, S. Liao, Y. Tang, J. Am. Chem. Soc. 2015, 137, 8006; g) D. D. Borisov, R. A. Novikov, Y. V. Tomilov, Angew. Chem. Int. Ed. 2016, 55, 12233; h) S. Racine, B. Hegedus, R. Scopelliti, J. Waser, Chem. Eur. J. 2016, 22, 11997; i) J. Blom, A. Vidal-Albalat, J. Jørgensen, C. L. Barløse, K. S. Jessen, M. V. Iversen, K. A. Jørgensen, Angew. Chem. Int. Ed. 2017, 56, 11831; j) R. Dey, P. Banerjee, Org. Lett 2017, 19, 304; k) A. Lücht, L. J. Patalag, A. U. Augustin, P. G. Jones, D. B. Werz, Angew. Chem. Int. Ed. 2017, 56, 10587; I) R. A. Novikov, A. V. Tarasova, D. A. Denisov, D. D. Borisov, V. A. Korolev, V. P. Timofeev, Y. V. Tomilov, J. Org. Chem. 2017, 82, 2724

[23] D. W. J. Cruickshank, Acta Cryst 1956, 9, 915.

[24] a) G. M. Sheldrick, Acta Cryst 2008, A64, 112; b) R. Bucourt, D. Hainaut, Bull. Soc. Chim. Fr. 1965, 1366. 


\section{Entry for the Table of Contents}

\section{FULL PAPER}

The unique nucleophilicity of 3,3 '-linked bispyrroles at their 2-positions towards several carbon electrophiles is investigated. 1,2-Diketone bridges, which serve as key intermediates to extended $\pi$-systems, were installed. Oxidative conditions afforded a uniquely linked linear tetrapyrrole.

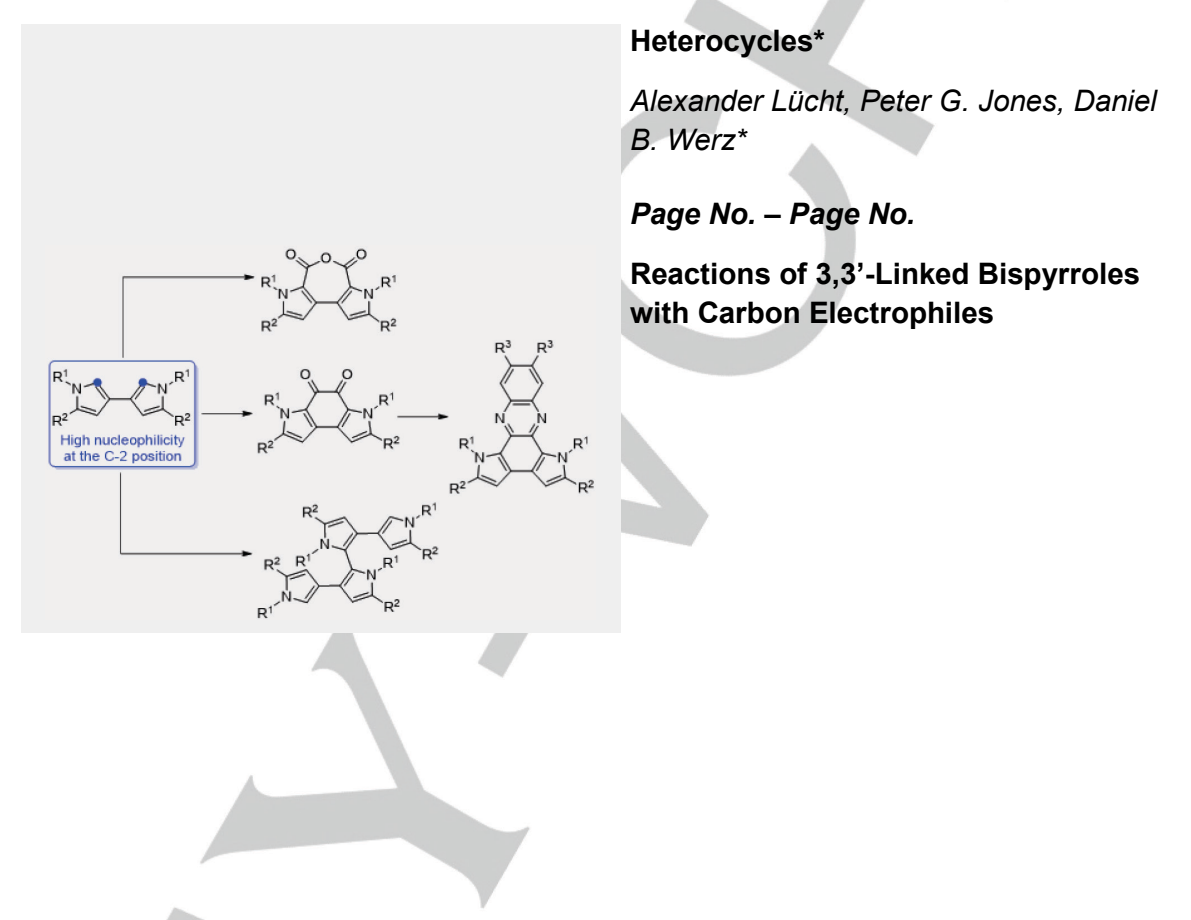

